\title{
The platelet paradox of injury versus protection in myocardial infarction-has it been overlooked?
}

\author{
Petra Kleinbongard ${ }^{1}$ (1) $\cdot$ Ioanna Andreadou ${ }^{2} \cdot$ Gemma Vilahur $^{3,4}$
}

Received: 26 April 2021 / Accepted: 26 April 2021 / Published online: 26 May 2021

(c) The Author(s) 2021

The rupture of an atherosclerotic plaque triggers platelet activation and thrombus formation, often resulting in coronary occlusion and acute myocardial infarction (MI) [3]. Accordingly, the use of antiplatelet therapy has become the standard of care in acute coronary syndromes to attenuate and reduce recurrent thrombotic events. However, the clinical benefit of $\mathrm{P} 2 \mathrm{Y}_{12}$ receptor antagonists is not limited to their ability to inhibit platelet function and prevent arterial thrombus formation but they have been shown to also provide direct cardioprotective effects $[37,56]$.

In the study by Dr. Hjortbak and collaborators [23], the authors retrospectively examined data from the CONDI-2/ ERIC-PPCI trial. The CONDI-2/ERIC-PPCI trial was an international, multicentre, single-blinded, randomized controlled trial comprising 5401 ST-segment elevation myocardial infarction (STEMI) patients [19]. Patients were randomly assigned to receive either standard treatment or remote ischemic conditioning (RIC), initiated prior to primary percutaneous coronary intervention (PPCI). RIC, brief cycles of ischemia and reperfusion applied to an organ or tissue remote from the heart, has been shown to reduce myocardial damage after myocardial ischemia/reperfusion (IR) in animal models but also in humans [21]. The ability to deliver the cardioprotective RIC stimulus by simply inflating

This comment refers to the article available at https://doi.org/10. 1007/s00395-021-00870-y.

Petra Kleinbongard

petra.kleinbongard@uk-essen.de

1 Institute for Pathophysiology, West German Heart and Vascular Center, University of Essen Medical School, University of Duisburg-Essen, Hufelandstr. 55, 45122 Essen, Germany

2 Laboratory of Pharmacology, Faculty of Pharmacy, National and Kapodistrian University of Athens, Athens, Greece

3 CIBERCV, Instituto Salud Carlos III, Madrid, Spain

4 Cardiovascular Research Chair Autonomous University of Barcelona (UAB), Barcelona, Spain and deflating a pneumatic cuff placed on the upper arm or thigh has facilitated the translation of RIC into the clinical setting [17, 21, 26]. In the CONDI-2/ERIC-PPCI trial, the primary endpoint was a combination of cardiac death or hospitalization for heart failure at 12 months post-randomization. Secondary endpoints included major cardiovascular and cerebral adverse events at 30 days and 12 months and myocardial damage in a subset of 2662 patients estimated from biomarker release over $48 \mathrm{~h}$ after PPCI [19]. However, and unfortunately, this trial failed to confirm prior single center studies $[11,20,22]$. There was no difference between the control group and the RIC group in the combined primary endpoint of cardiac death or heart failure or in major cardiovascular and cerebral adverse events or myocardial damage [19].

Now, the group by Dr. Botker has taken advantage of these neutral findings to retrospectively investigate the potential protective effects of the most commonly prescribed P2Y 12 receptor antagonists - clopidogrel, prasugrel and ticagrelor-on cardiac damage post-MI and clinical outcome [23]. Undoubtedly, this retrospective analysis touches upon a topic of high clinical interest. On one hand, novel and innovative treatment strategies are needed to limit the infarct size, preserve left ventricular function and improve clinical outcomes in STEMI patients undergoing PPCI [2, 10, 18, 33-35]. On the other hand, this multicentre study expands on the reported existence of potential differences in cardioprotection achieved with the most widely prescribed $\mathrm{P} 2 \mathrm{Y}_{12}$ receptor antagonists and demonstrates a benefit of ticagrelor over clopidogrel and prasugrel in clinical outcomes. As such, as compared to clopidogrel, the composite endpoint of cardiac death or hospitalization for heart failure was reduced in STEMI patients treated with ticagrelor, but not prasugrel [23]. Platelet $\mathrm{P} 2 \mathrm{Y}_{12}$ receptor antagonists are thought to induce cardioprotection through conditioning mimetic effects $[45,56]$ and thus to potentially limit further protection from additional ischemic conditioning [8, 25]. Yet, an increasing number of experimental and small clinical studies 
have suggested, that ticagrelor exerts cardioprotection and attenuates adverse cardiac remodelling post-MI to a larger extent than clopidogrel through its platelet-independent effects $[1,38,51]$. In this regard, ticagrelor has been shown to increase the circulating levels of adenosine, an endogenous cardioprotective substance, by inhibiting its uptake through the equilibrative nucleoside transporter 1 receptor [6]. Furthermore, ticagrelor administration has been associated in a pig model of MI with enhanced expression and activation of adenosine monophosphate-activated (AMPK) and reduced aquaporine- 4 levels in the ischemic myocardium as compared to clopidogrel-treated animals [52, 53]. In the study by Dr. Hjortbak [23], the authors reproduced the clinical data in an in vivo rat model of IR-ticagrelor reduced infarct size, clopidogrel and prasugrel did not. Doses and timing of the $\mathrm{P}_{2} \mathrm{Y}_{12}$ receptor antagonists were chosen from the literature. However, as discussed by the authors, potential differences in their pharmacokinetic (drug concentrations) or pharmacodynamic (degree of platelet inhibition) profile at reperfusion, that could partly explain ticagrelor's superiority over prasugrel and clopidogrel, were not excluded. Yet, ticagrelor's superiority was evidenced in both the preclinical and clinical data. Future studies should aim to determine the cellular targets and signaling pathways by which ticagrelor contributes to such beneficial effects.

This paper, however, overlooks one crucial aspect: the paradoxical role of platelets in the setting of MI. Activated platelets, beyond promoting arterial thrombus formation, may contribute to cardiac damage via different mechanisms, including the formation of coronary microvascular microthrombi, induction of platelet-leukocyte interactions, release of vasoconstrictor molecules (e.g., thromboxane A2), and (microRNA-containing) microvesicles [4, 9]. However, increasing evidence supports the notion that platelets also carry and release multiple factors with the potential to reduce rather than promote IR injury (Fig. 1) [9, 13]! Whereas the injurious role of platelets is mainly attributed to its (intra-)vascular actions, platelet protective effects are mainly mediated through their secreted factors on cardiomyocytes. Platelets contain sphingosine kinase, which, upon activation, can transform membrane sphingosine into sphingosine-1 phosphate (S1P), a pivotal mediator of cardioprotection [24, 49, 54]. Multiple studies have demonstrated the ability of platelet-derived S1P to protect against IR injury by activating the survivor activating factor enhancement (SAFE), reperfusion injury salvage kinase (RISK), and protein kinase B (Akt)/endothelial nitric oxide synthase cardioprotective signaling pathways $[32,50]$. Furthermore, adenosine nucleotides and serotonin released from dense granules have demonstrated tissue-protective effects, and stromal cellderived factor $1 \alpha(\mathrm{SDF} 1 \alpha)$ and transforming growth factor $\beta 1$ (TGF $\beta 1$ ) released from alpha granules have been shown to reduce IR injury in rodent and human myocardium [12],

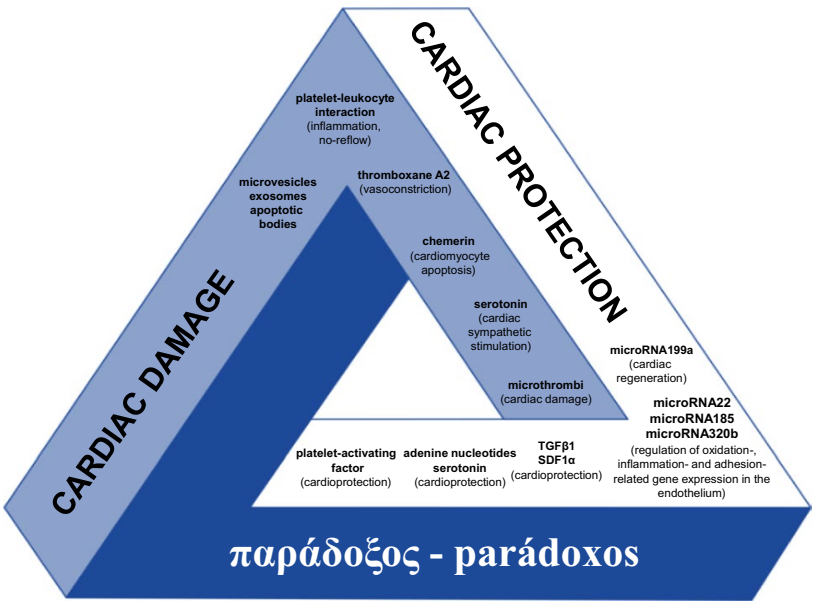

Fig. 1 The platelet paradox. Paradox-from the ancient Greek adjective $\pi \alpha \rho \alpha ́ \delta$ o̧os parádoxos [29], "i.e., contrary to expectation, unexpected, incredible": platelets contribute to cardiac damage during myocardial infarction, but also carry and release multiple cardioprotective factors. Our understanding of platelets in the setting of acute myocardial infarction is not complete-it only appears to be a closed structure-as with the "Penrose triangle". The British Nobel Prizewinning mathematician Sir Roger Penrose popularized this triangle, which gives the appearance of a closed three-dimensional structure of three right angles, but in the Euclidean geometry it cannot exist as a solid object [40]. SDF1 $\alpha$ : stromal cell-derived factor-1 $\alpha$, and TGF $\beta 1$ : transforming growth factor $\beta 1$

and to delay the rate of cardiomyocyte death by activating the RISK and SAFE pathways [46, 55]. Platelets also carry microRNAs, known to exert beneficial effects on cardiac IR, regulate endothelial gene expression and promote cardiac regeneration (Fig. 1) [9]. An in-depth understanding of the role of platelet-derived components on infarct size and cardioprotection in the setting of MI will allow to properly tackle the potential of $\mathrm{P} 2 \mathrm{Y}_{12}$ receptor antagonists to limit cardiac damage beyond arterial thrombus formation and growth. It is conceivable that the administration of $\mathrm{P} 2 \mathrm{Y}_{12}$ receptor antagonists may interfere with the protective role of platelets during MI [36], making things more complex.

This paper also makes us wonder what the potential impact of RIC on platelet function is. In a recent substudy of the CONDI-2/ERIC-PPCI trial that included 53 patients with RIC versus 47 without, RIC was associated with a reduction in platelet reactivity within the first $48 \mathrm{~h}$ postSTEMI [15], confirming a prior single-center trial, where RIC was associated with a reduction in the exercise-related increase of platelet reactivity in patients with obstructive coronary artery disease [5]. RIC has also been shown to prevent systemic platelet activation associated with IR injury in humans [39], to decrease the conformation changes of platelet GPIIb/IIIa (a marker of platelet activation) [28] and platelet-monocyte aggregate formation $[27,28,48]$ in patients with suspected stable angina undergoing coronary angiography $[27,28]$ and in those undergoing ablation for 
atrial fibrillation [48]. These clinical data support previous experimental findings in animal models of myocardial IR injury in which ischemic conditioning approaches attenuated platelet activation, aggregation and overall plateletmediated arterial thrombus formation $[16,30]$. However, although RIC abrogated the increase in platelet-monocyte aggregation in healthy volunteers, no effect was detected in circulating platelet-neutrophil complexes, and long-term RIC (once/day for $28 \pm 4$ days) did not alter platelet function in patients with chronic ischemic heart failure [41]. Nevertheless, altogether these data suggest the ability of ischemic conditioning to modulate platelet behaviour in the setting of MI regardless of the antiplatelet background and urges the need to decipher the molecular mechanisms involved, particularly since $\mathrm{P} 2 \mathrm{Y}_{12}$ blockade recapitulates protective signal transduction pathways triggered by ischemic conditioning approaches $[8,25]$. Future studies should aim to contribute to a better understanding of the basic mechanism(s) of platelet involvement in RIC and investigate in-depth the possible cardioprotective effects of antiplatelet agents that are already used in STEMI patients.

Given the current exceptional situation, a final thought relates to a further platelet paradox in COVID-19 and its current treatment options. SARS-CoV2 is associated with platelet hyperreactivity [7, 14, 43], and some of the vaccination strategies against coronavirus have been suggested to activate platelets [31]. Yet, mounting evidence has indicated that the granular content of platelets plays a critical role in innate immunology in the lung [44], thereby promoting platelet-dependent properties as a therapeutic option for the treatment of COVID-19 [42]. The role of platelets and the impact of antiplatelet approaches [47] in this scenario remain to be explored.

The collaboration of the authors was supported by European COST Action EU-CARDIOPROTECTION COSTACTION (CA16225).

Funding Open Access funding enabled and organized by Projekt DEAL

Open Access This article is licensed under a Creative Commons Attribution 4.0 International License, which permits use, sharing, adaptation, distribution and reproduction in any medium or format, as long as you give appropriate credit to the original author(s) and the source, provide a link to the Creative Commons licence, and indicate if changes were made. The images or other third party material in this article are included in the article's Creative Commons licence, unless indicated otherwise in a credit line to the material. If material is not included in the article's Creative Commons licence and your intended use is not permitted by statutory regulation or exceeds the permitted use, you will need to obtain permission directly from the copyright holder. To view a copy of this licence, visit http://creativecommons.org/licenses/by/4.0/.

\section{References}

1. Audia JP, Yang XM, Crockett ES, Housley N, Haq EU, O'Donnell K, Cohen MV, Downey JM, Alvarez DF (2018) Caspase-1 inhibition by VX-765 administered at reperfusion in P2Y12 receptor antagonist-treated rats provides long-term reduction in myocardial infarct size and preservation of ventricular function. Basic Res Cardiol 113:32. https://doi.org/10.1007/s00395-018-0692-z

2. Badimon L, Mendieta G, Ben-Aicha S, Vilahur G (2019) Postgenomic methodologies and preclinical animal models: chances for the translation of cardioprotection to the clinic. Int J Mol Sci 20:514. https://doi.org/10.3390/ijms20030514

3. Badimon L, Vilahur G (2014) Thrombosis formation on atherosclerotic lesions and plaque rupture. J Intern Med 276:618-632. https://doi.org/10.1111/joim.12296

4. Badimon L, Vilahur G, Rocca B, Patrono C (2021) The key contribution of platelet and vascular arachidonic acid metabolism to the pathophysiology of atherothrombosis. Cardiovasc Res. https:// doi.org/10.1093/cvr/cvab003

5. Battipaglia I, Scalone G, Milo M, Di Franco A, Lanza GA, Crea F (2011) Upper arm intermittent ischaemia reduces exercise-related increase of platelet reactivity in patients with obstructive coronary artery disease. Heart 97:1298-1303. https://doi.org/10.1136/hrt. 2011.226415

6. Bonello L, Laine M, Kipson N, Mancini J, Helal O, Fromonot J, Gariboldi V, Condo J, Thuny F, Frere C, Camoin-Jau L, Paganelli F, Dignat-George F, Guieu R (2014) Ticagrelor increases adenosine plasma concentration in patients with an acute coronary syndrome. J Am Coll Cardiol 63:872-877. https://doi.org/10.1016/j. jacc.2013.09.067

7. Canzano P, Brambilla M, Porro B, Cosentino N, Tortorici E, Vicini S, Poggio P, Cascella A, Pengo MF, Veglia F, Fiorelli S, Bonomi A, Cavalca V, Trabattoni D, Andreini D, Omodeo Sale E, Parati G, Tremoli E, Camera M (2021) Platelet and endothelial activation as potential mechanisms behind the thrombotic complications of COVID-19 patients. JACC Basic Transl Sci. https:// doi.org/10.1016/j.jacbts.2020.12.009

8. Cohen MV, Downey JM (2014) Combined cardioprotectant and antithrombotic actions of platelet $\mathrm{P} 2 \mathrm{Y} 12$ receptor antagonists in acute coronary syndrome: just what the doctor ordered. J Cardiovasc Pharmacol Ther 19:179-190. https://doi.org/10.1177/10742 48413508465

9. Davidson SM, Andreadou I, Barile L, Birnbaum Y, CabreraFuentes HA, Cohen MV, Downey JM, Girao H, Pagliaro P, Penna C, Pernow J, Preissner KT, Ferdinandy P (2019) Circulating blood cells and extracellular vesicles in acute cardioprotection. Cardiovasc Res 115:1156-1166. https://doi.org/10.1093/cvr/cvy314

10. Davidson SM, Ferdinandy P, Andreadou I, Bøtker HE, Heusch G, Ibanez B, Ovize M, Schulz R, Yellon DM, Hausenloy DJ, Garcia-Dorado D, Action CC (2019) Multitarget strategies to reduce myocardial ischemia/reperfusion injury: JACC review topic of the week. J Am Coll Cardiol 73:89-99. https://doi.org/10.1016/j.jacc. 2018.09.086

11. Gaspar A, Lourenco AP, Pereira MA, Azevedo P, Roncon-Albuquerque R Jr, Marques J, Leite-Moreira AF (2018) Randomized controlled trial of remote ischaemic conditioning in ST-elevation myocardial infarction as adjuvant to primary angioplasty (RICSTEMI). Basic Res Cardiol 113:14. https://doi.org/10.1007/ s00395-018-0672-3

12. Gawaz M (2004) Role of platelets in coronary thrombosis and reperfusion of ischemic myocardium. Cardiovasc Res 61:498-511. https://doi.org/10.1016/j.cardiores.2003.11.036

13. Gianazza E, Brioschi M, Baetta R, Mallia A, Banfi C, Tremoli E (2020) Platelets in healthy and disease states: from biomarkers 
discovery to drug targets identification by proteomics. Int $\mathrm{J}$ Mol Sci. https://doi.org/10.3390/ijms21124541

14. Gori T, Lelieveld J, Munzel T (2020) Perspective: Cardiovascular disease and the COVID-19 pandemic. Basic Res Cardiol 115:32. https://doi.org/10.1007/s00395-020-0792-4

15. Gorog DA, Farag M, Spinthakis N, Yellon DM, Botker HE, Kharbanda RK, Hausenloy DJ (2021) Effect of remote ischaemic conditioning on platelet reactivity and endogenous fibrinolysis in ST-elevation myocardial infarction: a substudy of the CONDI-2/ ERIC-PPCI randomized controlled trial. Cardiovasc Res 117:623634. https://doi.org/10.1093/cvr/cvaa061

16. Hata K, Whittaker P, Kloner RA, Przyklenk K (1998) Brief antecedent ischemia attenuates platelet-mediated thrombosis in damaged and stenotic canine coronary arteries. Role of adenosine. Circulation 97:692-702. https://doi.org/10.1161/01.CIR.97.7.692

17. Hausenloy DJ, Barrabes JA, Bøtker HE, Davidson SM, Di Lisa F, Downey J, Engstrom T, Ferdinandy P, Carbrera-Fuentes HA, Heusch G, Ibanez B, Iliodromitis EK, Inserte J, Jennings R, Kalia N, Kharbanda R, Lecour S, Marber M, Miura T, Ovize M, PerezPinzon MA, Piper HM, Przyklenk K, Schmidt MR, Redington A, Ruiz-Meana M, Vilahur G, Vinten-Johansen J, Yellon DM, Garcia-Dorado D (2016) Ischaemic conditioning and targeting reperfusion injury: a 30 year voyage of discovery. Basic Res Cardiol 111:70. https://doi.org/10.1007/s00395-016-0588-8

18. Hausenloy DJ, Heusch G (2019) Translating cardioprotection for patient benefit: the EU-CARDIOPROTECTION COST action. J Am Coll Cardiol 73:2001-2003. https://doi.org/10.1016/j.jacc. 2019.03.020

19. Hausenloy DJ, Kharbanda RK, Møller UK, Ramlall M, Aarøe J, Butler R, Bulluck H, Clayton T, Dana A, Dodd M, Engstrom T, Evans R, Flensted Lassen J, Frischknecht Christensen E, GarciaRuiz JM, Gorog DA, Hjort J, Houghton RF, Ibanez B, Knight R, Lippert FK, Lønborg JT, Maeng M, Milasinovic D, More R, Nicholas JM, Okkels Jensen L, Perkins A, Radovanovic N, Rakhit RD, Ravkilde J, Ryding AD, Schmidt MR, Skogstad Riddervold I, Toft Sørensen H, Stankovic G, Varma M, Webb I, Juhl Terkelsen C, Greenwood JP, Yellon DM, Bøtker HE (2019) Effect of remote ischemic conditioning on clinical outcomes at 12 months in acute myocardial infarction patients: the CONDI-2/ERIC-PPCI trial. Lancet 394:1415-1424. https://doi.org/10.1016/S0140-6736(19) 32039-2

20. Heusch G (2018) 25 years of remote ischemic conditioning: from laboratory curiosity to clinical outcome. Basic Res Cardiol 113:15. https://doi.org/10.1007/s00395-018-0673-2

21. Heusch G (2020) Myocardial ischaemia-reperfusion injury and cardioprotection in perspective. Nat Rev Cardiol 17:773-789. https://doi.org/10.1038/s41569-020-0403-y

22. Heusch G, Rassaf T (2016) Time to give up on cardioprotection? A critical appraisal of clinical studies on ischemic pre-, post-, and remote conditioning. Circ Res 119:676-695. https://doi.org/10. 1161/CIRCRESAHA.116.308736

23. Hjortbak MV, Olesen KKW, Seefeldt JM, Lassen TR, Jensen RV, Perkins A, Dodd M, Clayton T, Yellon D, Hausenloy DJ, Bøtker HE (2021) Translation of experimental cardioprotective capability of P2Y12 inhibitors into clinical outcome in patients with STelevation myocardial infarction. Basic Res Cardiol. https://doi. org/10.1007/s00395-021-00870-y

24. Keul P, van Borren MM, Ghanem A, Muller FU, Baartscheer A, Verkerk AO, Stumpel F, Schulte JS, Hamdani N, Linke WA, van Loenen P, Matus M, Schmitz W, Stypmann J, Tiemann K, Ravesloot JH, Alewijnse AE, Hermann S, Spijkers LJ, Hiller KH, Herr D, Heusch G, Schafers M, Peters SL, Chun J, Levkau B (2016) Sphingosine-1-phosphate receptor 1 regulates cardiac function by modulating $\mathrm{Ca} 2+$ sensitivity and $\mathrm{Na}+/ \mathrm{H}+$ exchange and mediates protection by ischemic preconditioning. J Am Heart Assoc 5:e003393. https://doi.org/10.1161/JAHA.116.003393

25. Kleinbongard P, Botker HE, Ovize M, Hausenloy DJ, Heusch G (2020) Co-morbidities and co-medications as confounders of cardioprotection - does it matter in the clinical setting? Br J Pharmacol. https://doi.org/10.1111/bph.14839

26. Kleinbongard P, Skyschally A, Heusch G (2017) Cardioprotection by remote ischemic conditioning and its signal transduction. Pflugers Arch Eur J Physiol 469:159-181. https://doi.org/10.1007/ s00424-016-1922-6

27. Lanza GA, Stazi A, Villano A, Torrini F, Milo M, Laurito M, Flego D, Aurigemma C, Liuzzo G, Crea F (2016) Effect of remote ischemic preconditioning on platelet activation induced by coronary procedures. Am J Cardiol 117:359-365. https://doi.org/10. 1016/j.amjcard.2015.10.056

28. Lau JK, Pennings GJ, Reddel CJ, Campbell H, Liang HPH, Traini M, Gardiner EE, Yong AS, Chen VM, Kritharides L (2020) Remote ischemic preconditioning inhibits platelet alphaIIb beta3 activation in coronary artery disease patients receiving dual antiplatelet therapy — a randomized trial. J Thromb Haemost 18:12211232. https://doi.org/10.1111/jth.14763

29. Liddell HG, Scott R (1996) A greek-english lexicon, revised and augmented by Sir Henry Stuard Jones. Clarendon Press, Oxford

30. Linden MD, Whittaker P, Frelinger AL III, Barnard MR, Michelson AD, Przyklenk K (2006) Preconditioning ischemia attenuates molecular indices of platelet activation-aggregation. J Thromb Haemost 4:2670-2677. https://doi.org/10.1111/j.1538-7836.2006. 02228.x

31. Mahase E (2021) COVID-19: Astrazeneca vaccine is not linked to increased risk of blood clots, finds european medicine agency. BMJ 372:n774. https://doi.org/10.1136/bmj.n774

32. Means CK, Xiao CY, Li Z, Zhang T, Omens JH, Ishii I, Chun J, Brown JH (2007) Sphingosine 1-phosphate S1P2 and S1P3 receptor-mediated akt activation protects against in vivo myocardial ischemia-reperfusion injury. Am J Physiol Heart Circ Physiol 292:H2944-H2951. https://doi.org/10.1152/ajpheart.01331.2006

33. Mendieta G, Ben-Aicha S, Casani L, Badimon L, Sabate M, Vilahur G (2019) Molecular pathways involved in the cardioprotective effects of intravenous statin administration during ischemia. Basic Res Cardiol 115:2. https://doi.org/10.1007/s00395-019-0760-z

34. Mendieta G, Ben-Aicha S, Casani L, Badimon L, Sabate M, Vilahur G (2019) Intravenous statin administration during ischemia exerts cardioprotective effects. J Am Coll Cardiol 74:475-477. https://doi.org/10.1016/j.jacc.2019.05.020

35. Mendieta G, Ben-Aicha S, Gutierrez M, Casani L, Arzanauskaite M, Carreras F, Sabate M, Badimon L, Vilahur G (2020) Intravenous statin administration during myocardial infarction compared with oral post-infarct administration. J Am Coll Cardiol 75:1386-1402. https://doi.org/10.1016/j.jacc.2020.01.042

36. Neal MD (2020) The great platelet paradox: evolution of platelet contribution to hemostasis, inflammation, and thrombosis after injury. Blood Adv 4:2556. https://doi.org/10.1182/bloodadvances. 2019001166

37. Nylander S, Schulz R (2016) Effects of P2Y12 receptor antagonists beyond platelet inhibition-comparison of ticagrelor with thienopyridines. Br J Pharmacol 173:1163-1178. https://doi.org/ 10.1111/bph.13429

38. Park Y, Koh JS, Lee JH, Park JH, Shin ES, Oh JH, Chun W, Lee SY, Bae JW, Kim JS, Kim W, Suh JW, Yang DH, Hong YJ, Chan MY, Kang MG, Park HW, Hwang SJ, Hwang JY, Ahn JH, Choi SW, Jeong YH, Investigators H-A (2020) Effect of ticagrelor on left ventricular remodeling in patients with ST-segment elevation myocardial infarction (HEALING-AMI). JACC Cardiovasc Interv 13:2220-2234. https://doi.org/10.1016/j.jcin.2020.08.007 
39. Pedersen CM, Cruden NL, Schmidt MR, Lau C, B $\varnothing$ tker HE, Kharbanda RK, Newby DE (2011) Remote ischemic preconditioning prevents systemic platelet activation associated with ischemiareperfusion injury in humans. J Thromb Haemost 9:404-407. https://doi.org/10.1111/j.1538-7836.2010.04142.x

40. Penrose LS, Penrose R (1958) Impossible objects: a special type of visual illusion. Br J Psychol 49:31-33. https://doi.org/10. 1111/j.2044-8295.1958.tb00634.x

41. Pryds K, Kristiansen J, Neergaard-Petersen S, Nielsen RR, Schmidt MR, Refsgaard J, Kristensen SD, Botker HE, Hvas AM, Grove EL (2017) Effect of long-term remote ischaemic conditioning on platelet function and fibrinolysis in patients with chronic ischaemic heart failure. Thromb Res 153:40-46. https://doi.org/ 10.1016/j.thromres.2017.03.008

42. Qiu J, Ma J, Zhang S, Han J, Liu S (2020) Promoting platelets is a therapeutic option to combat severe viral infection of the lung. Blood Adv 4:1640-1642. https://doi.org/10.1182/bloodadvances. 2020001669

43. Rizzo P, Vieceli Dalla Sega F, Fortini F, Marracino L, Rapezzi C, Ferrari R (2020) COVID-19 in the heart and the lungs: could we "notch" the inflammatory storm? Basic Res Cardiol 115:31. https://doi.org/10.1007/s00395-020-0791-5

44. Rosowski EE, Huttenlocher A (2018) Motile collectors: Platelets promote innate immunity. Immunity 48:16-18. https://doi.org/10. 1016/j.immuni.2017.12.015

45. Roubille F, Lairez O, Mewton N, Rioufol G, Ranc S, Sanchez I, Cung TT, Elbaz M, Piot C, Ovize M (2012) Cardioprotection by clopidogrel in acute ST-elevated myocardial infarction patients: a retrospective analysis. Basic Res Cardiol 107:275. https://doi. org/10.1007/s00395-012-0275-3

46. Russo I, Femmino S, Barale C, Tullio F, Geuna S, Cavalot F, Pagliaro P, Penna C (2018) Cardioprotective properties of human platelets are lost in uncontrolled diabetes mellitus: a study in isolated rat hearts. Front Physiol 9:875. https://doi.org/10.3389/ fphys.2018.00875

47. Sahai A, Bhandari R, Koupenova M, Freedman JE, Godwin M, McIntyre T, Chung MK, Iskandar J-P, Kamran H, Hariri E, Aggarwal A, Kalra A, Bartholomew JR, McCrae KR, Elbadawi A, Svensson LG, Kapadia S, Cameron SJ (2020) SARS-CoV-2 receptors are expressed on human platelets and the effect of 1 aspirin on clinical 2 outcomes in COVID-19 patients. Preprint: https://doi.org/10.21203/rs.3.rs-119031/v1

48. Stazi A, Scalone G, Laurito M, Milo M, Pelargonio G, Narducci ML, Parrinello R, Figliozzi S, Bencardino G, Perna F, Lanza GA, Crea F (2014) Effect of remote ischemic preconditioning on platelet activation and reactivity induced by ablation for atrial fibrillation. Circulation 129:11-17. https://doi.org/10.1161/ CIRCULATIONAHA.113.005336

49. Theilmeier G, Schmidt C, Herrmann J, Keul P, Schafers M, Herrgott I, Mersmann J, Larmann J, Hermann S, Stypmann J, Schober O, Hildebrand R, Schulz R, Heusch G, Haude M, von Wnuck LK, Herzog C, Schmitz M, Erbel R, Chun J, Levkau B (2006) High-density lipoproteins and their constituent, sphingosine1-phosphate, directly protect the heart against ischemia/reperfusion injury in vivo via the S1P3 lysophospholipid receptor. Circulation 114:1403-1409. https://doi.org/10.1161/CIRCULATIO NAHA.105.607135

50. Vessey DA, Li L, Honbo N, Karliner JS (2009) Sphingosine 1-phosphate is an important endogenous cardioprotectant released by ischemic pre- and postconditioning. Am J Physiol Heart Circ Physiol 297:H1429-H1435. https://doi.org/10.1152/ajpheart. 00358

51. Vilahur G, Arzanauskaite M, Sutelman P (2020) Ticagrelor in post-STEMI adverse ventricular remodeling: there is more than meets the platelet. JACC Cardiovasc Interv 13:2235-2237. https:// doi.org/10.1016/j.jcin.2020.09.006

52. Vilahur G, Gutierrez M, Casani L, Lambert C, Mendieta G, BenAicha S, Capdevila A, Pons-Llado G, Carreras F, Carlsson L, Hidalgo A, Badimon L (2018) P2Y12 antagonists and cardiac repair post-myocardial infarction: global and regional heart function analysis and molecular assessments in pigs. Cardiovasc Res 114:1860-1870. https://doi.org/10.1093/cvr/cvy201

53. Vilahur G, Gutierrez M, Casani L, Varela L, Capdevila A, PonsLlado G, Carreras F, Carlsson L, Hidalgo A, Badimon L (2016) Protective effects of ticagrelor on myocardial injury after infarction. Circulation 134:1708-1719. https://doi.org/10.1161/CIRCU LATIONAHA.116.024014

54. Vito CD, Hadi LA, Navone SE, Marfia G, Campanella R, Mancuso ME, Riboni L (2016) Platelet-derived sphingosine-1-phosphate and inflammation: from basic mechanisms to clinical implications. Platelets 27:393-401. https://doi.org/10.3109/09537104. 2016.1144179

55. Walsh TG, Poole AW (2017) Platelets protect cardiomyocytes from ischaemic damage. TH Open 1:e24-e32. https://doi.org/10. 1055/s-0037-1603928

56. Yang XM, Liu Y, Cui L, Yang X, Liu Y, Tandon N, Kambayashi J, Downey JM, Cohen MV (2013) Platelet P2Y12 blockers confer direct postconditioning-like protection in reperfused rabbit hearts. J Cardiovasc Pharmacol Ther 18:251-262. https://doi.org/10. $1177 / 1074248412467692$ 